\title{
Study of the possibility of implementation in Finland of the Passivhaus concept in order to reduce energy consumption
}

\author{
Andreea Cristina Tataru ${ }^{1 *}$, Aurora Stanci ${ }^{2}$ \\ ${ }^{1}$ University of Petrosani, Department of Mechanical, Industrial and Transportation Engineering, 20 \\ Universitatii street, Petrosani, Romania \\ ${ }^{2}$ University of Petrosani, Department of Management, Environmental Engineering and Geology, 20 \\ Universitatii street, Petrosani, Romania
}

\begin{abstract}
Passive building has been defined by Wolfgang Feist, Passivhaus Institut, as being the building that demand for heating must not be more than $15 \mathrm{kWh} / \mathrm{m}^{2}$ year, and total consumption of primary energy should not be more than $120 \mathrm{kWh} / \mathrm{m}^{2}$ year. In this paper we strive to study at the concept of 'passive house' in the Finland. Using the Passive House Planning Package (PHPP) software 2007 calculate the heating requirements for such a House, depending on the latitude and climate conditions in the locality. For the study were selected 6 cities from Finland placed to different latitudes and climatic areas. To determine the possibility of implementing the concept "passive House" must be determined: required heating, cooling demand and primary energy demand. In order to implement this concept should not exceed maximum limits.
\end{abstract}

\section{Introduction}

Passive house concept was first introduced in Germany. Passive building has been defined by Wolfgang Feist, Passivhaus Institut, as being the building that demand for heating must not be more than $15 \mathrm{kWh} / \mathrm{m}^{2}$ year, and total consumption of primary energy should not be more than $120 \mathrm{kWh} / \mathrm{m}^{2}$ year

We ask ourselves if this passive building concept also applies to diferent latitudes than those of Germany. In this paper we propose to study the possibility of implementing the concept of "Passivehaus" in cities located at different latitudes on Finland territory. [1], [2], $[3],[4],[5]$

\section{Area description}

Finland, is a northern country located in the Finoscandic region of Northern Europe. It borders Sweden on the west, Norway to the north and Russia to the east, while Estonia is south, across the Gulf of Finland.

\footnotetext{
* Corresponding author: andreeastanci@yahoo.com
} 
The main factor influencing Finland's climate is the country's position between the 60 and 70 degrees north latitude in the coastal area of the Eurasian continent. In the Koppen climatic classification, all of Finland is in the subpolar climate zone characterized by warm summers and cold winters. Within the country, tempering rates vary considerably between southern coastal and northern regions, with ocean climate and continental climate characteristics.

Winters in southern Finland (when the average daily temperature remains below $0^{\circ} \mathrm{C}$ ) usually last for 100 days, and the snow covers the land from late November to mid-April. Even in temperate regions in the south, long and cold winter nights make the temperature drop to $-30^{\circ} \mathrm{C}$. Summer climate (periods with a mean temperature above $10^{\circ} \mathrm{C}$ ) lasts in southern Finland from the end of May to mid-September, and within the continent, the warmest July days can reach $35^{\circ} \mathrm{C}$.

The localities chosen for the study are located at different latitudes in Finland and are Helsinki, Jyväskylä, Kuopio, Oulu, Sodankylä, Vaasa. (Fig. 1.)

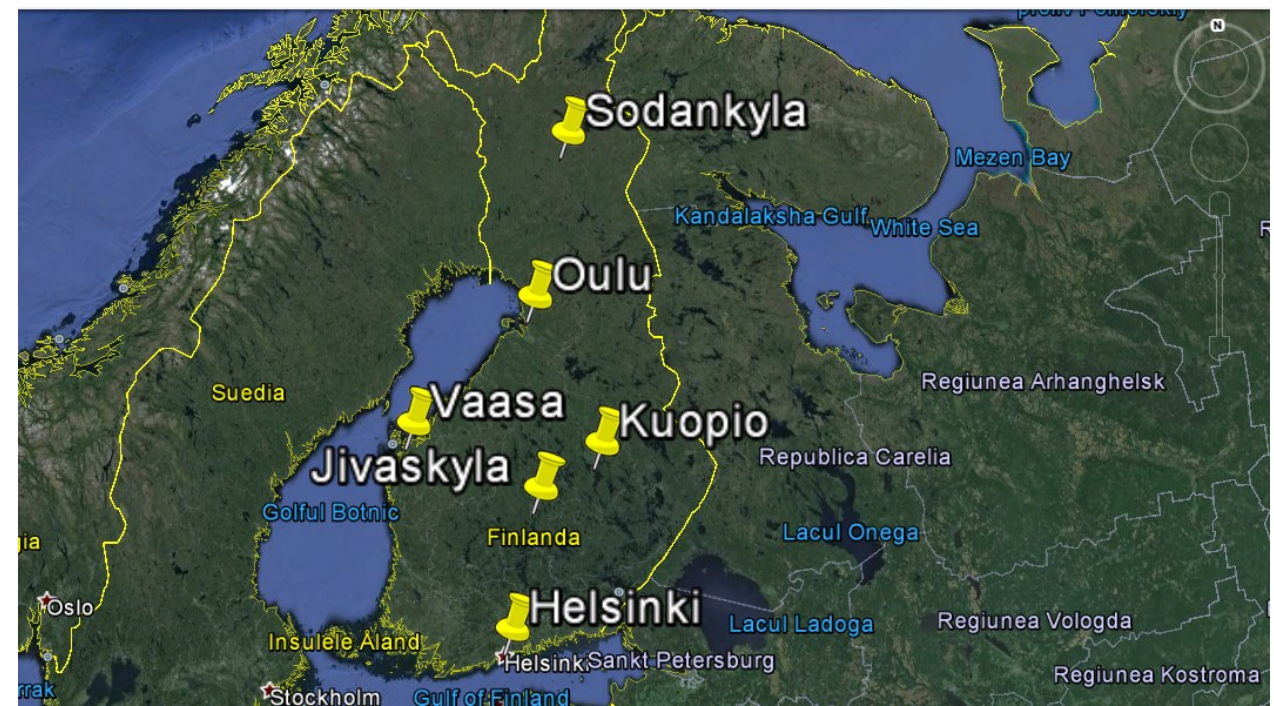

Fig. 1. Geographic location of cities for Finland

Climatic data on average monthly irradiance, average monthly irradiation, average monthly humidity, average monthly temperature for these cities to be studied are shown in Figures 2 - 5.

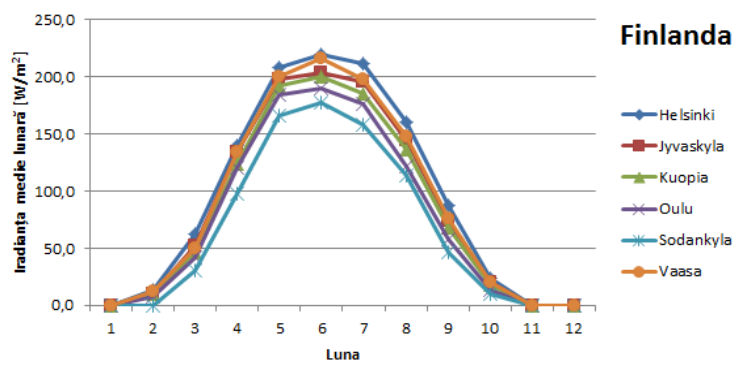

Fig. 2. Average monthly irradiance for Finland $\left(\mathrm{W} / \mathrm{m}^{2}\right)$ 


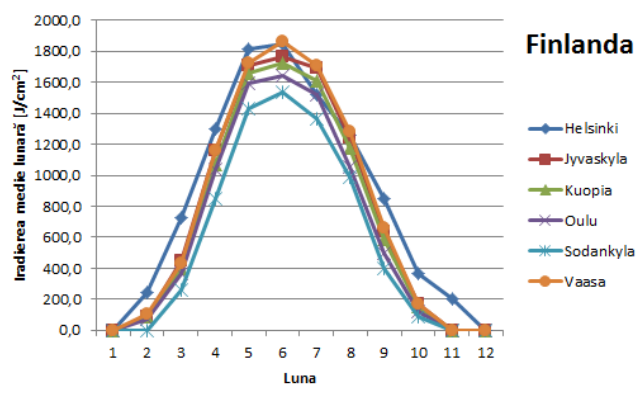

Fig. 3. Average monthly irradiation Finland $\left(\mathrm{J} / \mathrm{cm}^{2}\right)$

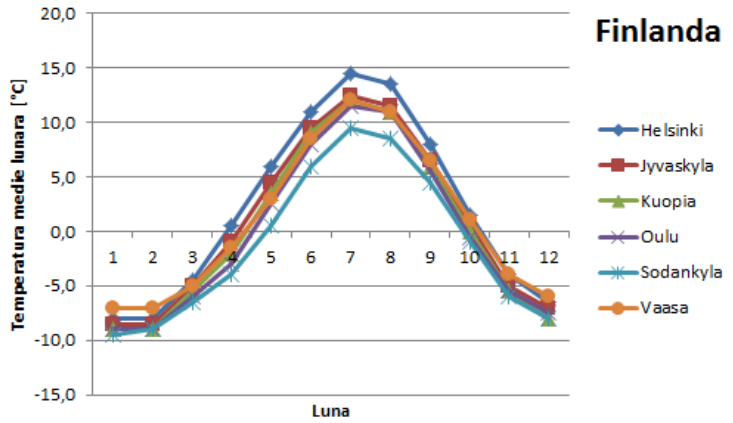

Fig. 4. Average monthly temperature Finlanda $\left({ }^{0} \mathrm{C}\right)$

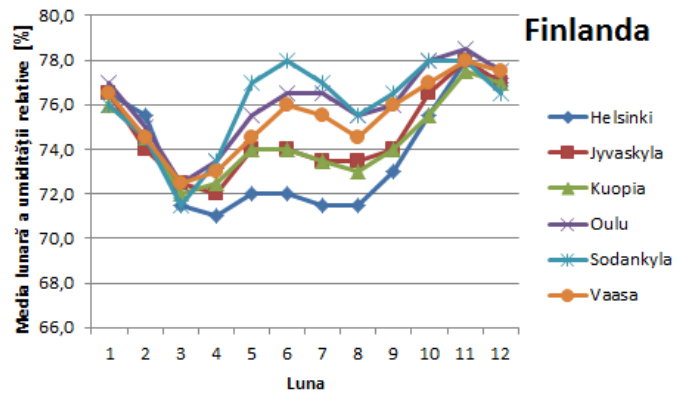

Fig. 5. Average monthly humidity for Finland (\%)

\section{Evaluation and interpretation of data obtained for the construction of passive houses in the areas studied}

Passive building requirements are not limited to certain climatic zones, but in some climate zones, passive buildings can only be achieved by increasing the thermal insulation through the use of top quality windows and by implementing a ventilation system with heat recovery efficiently. Such buildings can also use renewable heat sources such as solar heat or underground heat exchange.

Arctic climate is a big challenge in this field. For a house to meet the requirements to be considered a building passive zone climate arctic isolation level should be very high, and solar earnings are in some areas completely missing or higher only during certain times of the year and recovery systems heat are often blocked by ice formation. 
To study the viability of implementing passive houses in climate zones that are located at higher latitudes of 60 degrees north latitude, we intend to study the feasibility of the concept of the passive house.

For a better interpretation of the final results it is necessary to determine the types of climates and characteristics. To determine climatic zones, we use Koppen climate classification system.

Conform acestui system de clasificare toate Helsinki se află în zona DFB - Continental umed (veri calde, ierni severe, umede, fără sezon uscat) îar restul orașelor studiate în zona DFC - Subarctic (veri răcoroase, ierni severe, fără sezon uscat)

For this study were processed climatic data (average monthly climatological database of solar radiation, temperature and relative humidity) were taken from the site www.sodais.com.(soda-is) [6]

Climatic data were processed using programs Fortran and introduced in Passive House Planning Package (PHPP) 2007 program.

Climatic data results after running the Fortran program (figure 6) are selected (figure 7) and introduced in the climatic data sheet în Passive House Planning Package (PHPP) 2007 program (figure 8).

\begin{tabular}{|c|c|c|c|c|c|c|c|c|c|c|c|c|c|c|c|c|c|c|c|c|c|c|}
\hline$\theta . \theta$ & 0.0 & 0.0 & -10.0 & -4.5 & & .0 & 2.0 & 31.0 & 5.5 & & & & & & & & \\
\hline 12.0 & 9.0 & 184.0 & -9.5 & -5.0 & & .0 & 9.5 & 9.5 & 4.5 & $\begin{array}{l}1 \\
2\end{array}$ & $\begin{array}{l}-7,0 \\
-7,8\end{array}$ & $\begin{array}{l}-10,4 \\
-10,8\end{array}$ & $\begin{array}{l}-11,7 \\
-12,1\end{array}$ & $\begin{array}{l}-24,8 \\
-24,9\end{array}$ & $\begin{array}{l}-33,5 \\
-33,5\end{array}$ & $\begin{array}{l}-13,0 \\
-13,0\end{array}$ & & & & & \\
\hline 50.0 & 38.0 & 432.8 & -8.5 & -1.5 & & 5.0 & 6.5 & 8.5 & 2.5 & 3 & 5,8 & $-9,2$ & $-10,5$ & $-22,5$ & $-30,8$ & $-11,0$ & \multirow{2}{*}{\multicolumn{6}{|c|}{$\begin{array}{l}-25,6 \\
-24,1\end{array}$}} \\
\hline 134.0 & 101.0 & 1158.0 & -5.5 & 2.5 & & 1.5 & 7.0 & 8.5 & 3.0 & $\begin{array}{l}3 \\
4\end{array}$ & -1,5 & $-5,7$ & $-6,9$ & $-18,1$ & $-26,0$ & $-7,5$ & \multirow{2}{*}{\multicolumn{4}{|c|}{$\begin{array}{l}-24,1 \\
-21,2\end{array}$}} & & \\
\hline 200.0 & 150.0 & 1728.0 & -0.5 & 6.5 & & 3.0 & 9.0 & 9.5 & 4.5 & $\begin{array}{l}4 \\
5\end{array}$ & 3,0 & $-1,1$ & $-2,1$ & $-12,3$ & $-19,8$ & $-3,0$ & \multicolumn{4}{|c|}{$\begin{array}{l}-21,2 \\
-17,0\end{array}$} & & \\
\hline 216.0 & 162.0 & 1866.8 & 4.5 & 12.5 & & 3.5 & 1.5 & 30.5 & 5.0 & 6 & 8,5 & 4,5 & 3,7 & $-5,3$ & $-12,2$ & 2,5 & \multirow{2}{*}{\multicolumn{6}{|c|}{$\begin{array}{r}-10,8 \\
-6,3\end{array}$}} \\
\hline $\begin{array}{l}198.0 \\
148.0\end{array}$ & $\begin{array}{l}149.0 \\
111.0\end{array}$ & $\begin{array}{l}1711.0 \\
1279.8\end{array}$ & $\begin{array}{l}8.8 \\
7.5\end{array}$ & $\begin{array}{l}15.5 \\
14.5\end{array}$ & & 2.0 & 1.0 & 30.0 & 5.5 & 7 & $12, \theta$ & 7,8 & 7,1 & 9 & $-7,4$ & 6,0 & & & & & & \\
\hline $\begin{array}{r}148.0 \\
76.0\end{array}$ & $\begin{array}{r}111.0 \\
57.0\end{array}$ & $\begin{array}{r}1279.8 \\
657.8\end{array}$ & $\begin{array}{l}7.5 \\
3.0\end{array}$ & $\begin{array}{l}14.5 \\
10.0\end{array}$ & & 1.0 & $\theta .0$ & $\begin{array}{l}9.0 \\
30.5\end{array}$ & 4.5 & 8 & $11, \theta$ & 6,6 & 5,9 & $-2,2$ & $-8,8$ & 5,0 & \multicolumn{6}{|c|}{$\begin{array}{l}-6,3 \\
-7,6\end{array}$} \\
\hline 20.0 & 15.0 & 173.0 & -2.0 & 3.5 & & 1.0 & $\begin{array}{l}1.6 \\
2.5\end{array}$ & 30.5 & 5.0 & 9 & 6,5 & 2,6 & 1,7 & $-7,8$ & $-15,0$ &, 5 & \multicolumn{6}{|c|}{$\begin{array}{r}-7,6 \\
-13,1\end{array}$} \\
\hline 0.0 & 0.0 & 0.0 & -6.5 & -1.5 & & 1.0 & 3.5 & 32.8 & 8.0 & 10 & 1,0 & $-2,6$ & $-3,6$ & $-14,7$ & $-22,6$ & $-5,0$ & \multicolumn{6}{|c|}{$\begin{array}{l}-13,1 \\
-18,9\end{array}$} \\
\hline 0.0 & 0.0 & 0.0 & -8.5 & $-4,0$ & & 5.0 & 2.5 & 32.0 & $\begin{array}{l}3.8 \\
7.5\end{array}$ & 11 & $-4,0$ & $-7,3$ & $-8,4$ & $-20,9$ & $-29,4$ & $-10, \theta$ & \multicolumn{6}{|c|}{$\begin{array}{l}-18,9 \\
-23,3\end{array}$} \\
\hline 88.0 & 66.0 & 760.0 & -2.5 & 4.0 & & 1.0 & 0.5 & 30.0 & $\begin{array}{l}5.5 \\
5.5\end{array}$ & 12 & $-6,0$ & $-9,3$ & $-10,5$ & $-23,5$ & $-32,1$ & $-12,0$ & \multicolumn{6}{|c|}{$\begin{array}{l}-23,3 \\
-24,9\end{array}$} \\
\hline \multicolumn{5}{|c|}{ nord - Notepad } & \multicolumn{6}{|c|}{ al sud-Notepad } & \multicolumn{6}{|c|}{ Det-Notepad } & \multicolumn{6}{|c|}{ a vest - Notepad } \\
\hline Editare $\mathrm{Fo}$ & mat Vira & alizare As: & & & Fisiser & Edtare $\mathrm{F}$ - & format Vizu & valizare Ajut & utor & & Fisier & Editore $F$ & ormat Vizu & ializare Aju & & & Fisiger & Editare & Format $V_{12}$ & zualizare Aju & itor & \\
\hline , & , & , & , & , & 1 & , & , & , & , & , & 1 & , & , 0 & , $\theta$ & , & , , | & 1 & , & , , & , & , & \\
\hline 12,0 & 0 & 4,0 & 1,2 & 5,2 & 2 & 12,0 & 20,1 & $4, \theta$ & 1,2 & 25,3 & 2 & 12,0 & 4,8 & 4,0 & 1,2 & 10,0 & 2 & 12,0 & 4,8 & 4,0 & 1,2 & 1 \\
\hline 50,0 & , & 13,7 & 5,1 & 18,8 & 3 & 50,0 & 52,2 & 13,7 & 5,1 & 71,0 & 3 & 50,0 & 18,9 & 13,7 & 5,1 & 37,7 & 3 & 50,0 & 18,9 & 13,7 & 5,1 & 37 \\
\hline 134,0 & 2,4 & 29,0 & 14,3 & 45,7 & 4 & 134,0 & 95,0 & 29,0 & 14,3 & 138,3 & 4 & 134,0 & 68,9 & 29,8 & 14,3 & 112,2 & 4 & $134, \theta$ & 68,9 & 29 , & 14,3 & 112 \\
\hline 200,0 & 19,0 & 39,0 & 21,4 & 79,5 & & 200,0 & 90,4 & 39,0 & 21,4 & 150,8 & & 200,0 & 93,4 & 39,0 & 21,4 & 153,9 & 5 & 200,0 & 93,4 & 39 , & 21,4 & 153 \\
\hline $216, \theta$ & 38,1 & 45,4 & 23,3 & 106,8 & 6 & $216, \theta$ & 71,3 & 45,4 & 23,3 & $140, \theta$ & 6 & 216,0 & 93,6 & 45,4 & 23,3 & $\begin{array}{l}162,3 \\
\end{array}$ & 6 & $\begin{array}{l}216,0,8 \\
216,\end{array}$ & $\begin{array}{l}93,4 \\
93,6\end{array}$ & 45,4 & $\begin{array}{l}21,4 \\
23,3\end{array}$ & $\begin{array}{l}153 \\
162\end{array}$ \\
\hline 198,0 & 33,9 & 43,6 & 21,5 & 99,0 & 7 & 198,0 & 69,7 & 43,6 & 21,5 & 134,8 & 7 & 198,0 & 87,7 & 43,6 & 21,5 & 152,8 & 7 & 198 , 8 & 87,7 & 43,6 & 21,5 & 152 \\
\hline 148,0 & 3,1 & 33,0 & 15,6 & 51,7 & 8 & $148, \theta$ & 77,7 & 33,0 & 15,6 & 126,2 & 8 & 148,0 & 59,9 & 33,0 & 15,6 & 108,4 & 8 & 148 , & 59,9 & 33,0 & 15,6 & 108. \\
\hline 76,0 & , & 20,0 & 8,0 & 28,0 & 9 & 76,0 & 66,3 & 20,0 & 8,0 & 94,4 & 9 & 76,0 & 33,4 & 20,0 & 8,0 & 61,4 & 9 & 76,8 & 33,4 & 20,0 & 8,0 & 61 \\
\hline 20,0 & , & 6,3 & 1,9 & 8,2 & 10 & 20,0 & 21,7 & 6,3 & 1,9 & 29,8 & 10 & 20,0 & 5,4 & 6,3 & 1,9 & 13,6 & 10 & $20, \theta$ & 5,4 & 6,3 & 1,9 & 13. \\
\hline , & 0 & , & , & , & 11 & , & , & , & , & , & 11 & , & , & 0 & , & , & 11 & , & , & , & , & \\
\hline , & ,0 & , & , & ,0 & 12 & , & , & , & , & 0 & 12 & , & , & , & , & , 0 & 12 & , & , & 0 & 0 & \\
\hline
\end{tabular}

Fig.6. Climatic data results after running the Fortran program

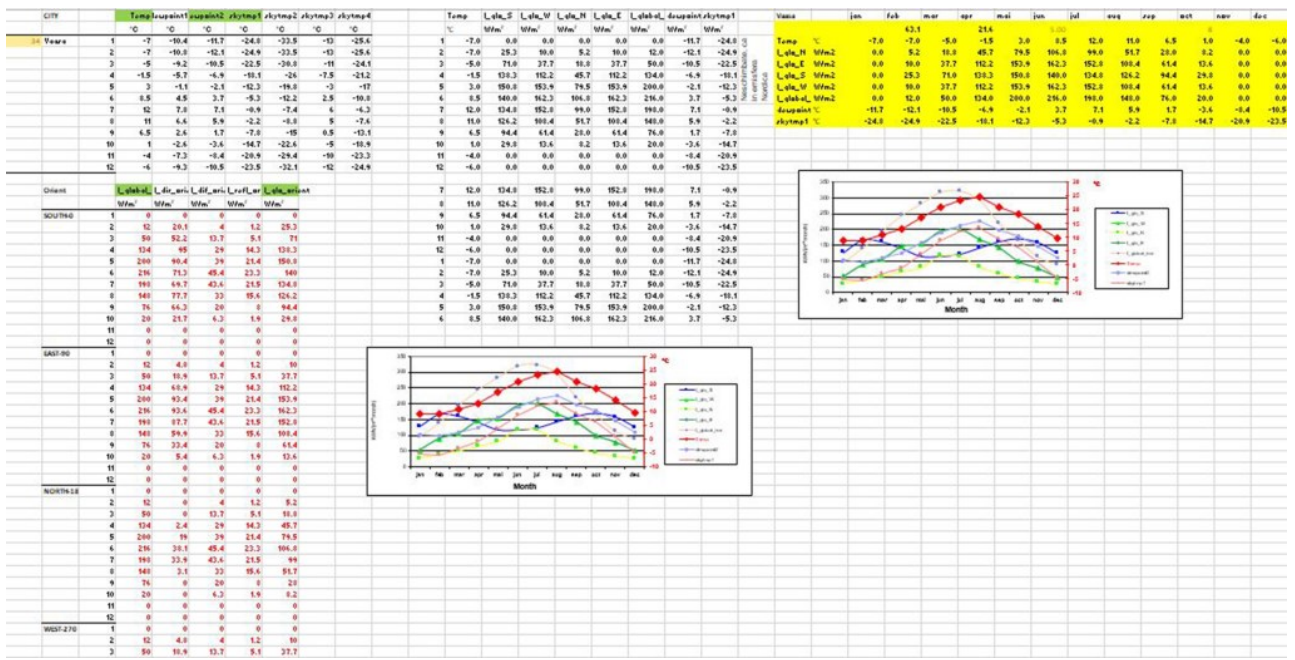

Fig. 7. Select climatic data for Passive House Planning Package 


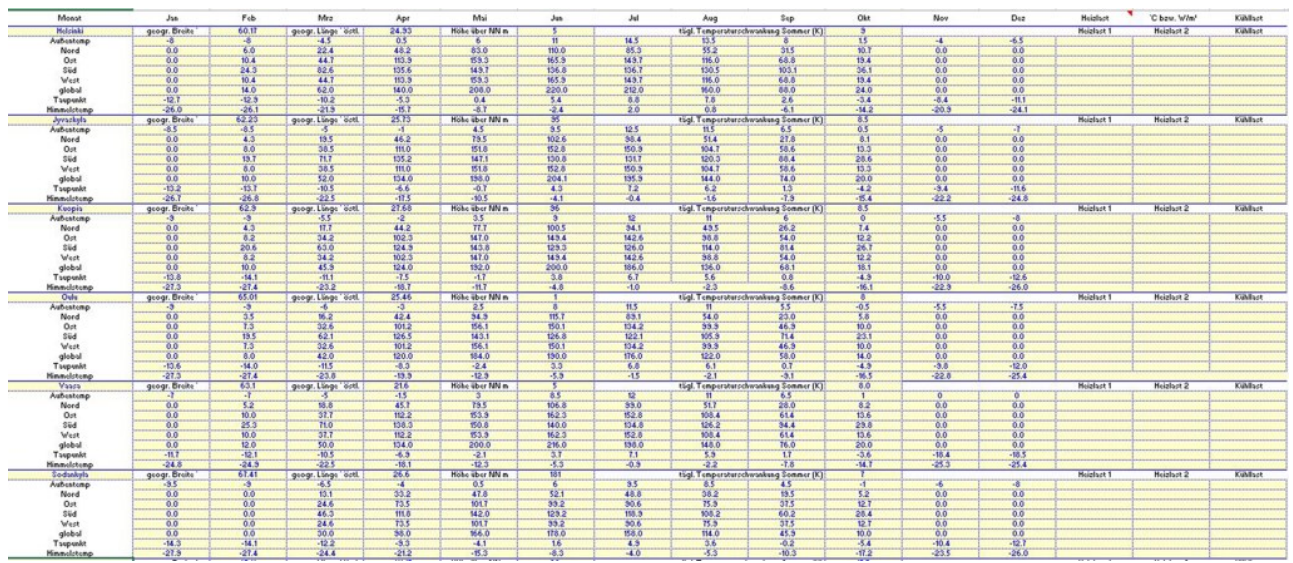

Fig. 8. Introduction of climate data in Passive House Planning Package (PHPP) 2007 program

The analysis was performed after the office building model Amvic.

Amvic building is structured as follows: ground floor, three floors and attic. The structure and main functions of the office building Amvic are: on the ground floor there is a large open space, secretarial and department office. In a separate area is a technique room. The first, second and third floor have office space. In the attic there are five apartments Amvic

Building envelope and interior divisions are separating elements with high thermal inertia. They are grouped into inner and outer walls respectively, roof, floor and plate. The outer walls are fitted with triple stratified low-e glazed.

After processing climate data and entering them into the computer program Passive House Planning Package (PHPP) 2007, we obtained results for Amvic house is a passive house office with an area of $2086 \mathrm{~m}^{2}$. Windows from the southern area of $156 \mathrm{~m}^{2}, 56,08 \mathrm{~m}^{2}$ northern, western and eastern $83,21 \mathrm{~m}^{2}$ of $42.35 \mathrm{~m}^{2}$.

Certification for a building like this passive building must meet for their heating requirements, and should be more than $15 \mathrm{kWh} / \mathrm{m}^{2}$.

Winter climate characteristics provides information about interactions between the main building and its environment. The average air temperature of winter is evaluated by using data for December, January and February in the Northern Hemisphere.

After processing climate data using PHPP 2007 program designed for the passive office building AMVIC, we have obtained the necessary heating for towns in Table 1.

The maximum permissible heating limit requirements defined for passive house is 15 $\mathrm{kWh} / \mathrm{m}^{2}$, this limit being exceeded in all the cities studied.

Table 1. The values obtained for the heating requirements for the passive office building AMVIC

\begin{tabular}{|l|l|l|l|l|l|l|}
\hline $\begin{array}{l}\text { Nr. } \\
\text { crt. }\end{array}$ & City & $\begin{array}{l}\text { Heating } \\
\text { needs } \\
\mathrm{kWh} / \\
\left(\mathrm{m}^{2} / \mathrm{an}\right)\end{array}$ & $\begin{array}{l}\text { Total primary } \\
\text { energy } \\
\text { consumption } \\
\mathrm{kWh} /\left(\mathrm{m}^{2} / \mathrm{an}\right)\end{array}$ & Latitudine & Longitudine & $\begin{array}{l}\text { Zonă } \\
\text { climatică } \\
\text { conform } \\
\text { Koppen }\end{array}$ \\
\hline 1 & Helsinki & 22 & 92 & 60,17 & 24,93 & Dfb \\
\hline 2 & Jyvaskyla & 23 & 93 & 62,23 & 25,73 & Dfc \\
\hline 3 & Kuopio & 25 & 94 & 62,9 & 27,68 & Dfc \\
\hline 4 & Oulu & 25 & 95 & 65,01 & 25,46 & Dfc \\
\hline 5 & Vaasa & 19 & 91 & 63,1 & 21,6 & Dfc \\
\hline 6 & Sodankyla & 28 & 96 & 67,41 & 26,6 & Dfc \\
\hline
\end{tabular}


Heating demand values vary between 19 and $28 \mathrm{kWh} /\left(\mathrm{m}^{2} /\right.$ year $)$. These values are specific to the climatic zones in which they are located. In the case of Vaasa where the heating demand is lower $\left(19 \mathrm{kWh} /\left(\mathrm{m}^{2} /\right.\right.$ year $\left.)\right)$, the performance of more efficient building insulation can reduce the heating demand below $15 \mathrm{kWh} /\left(\mathrm{m}^{2} /\right.$ year $)$ in order to be able falls within the limits imposed by the concept of passive house.

Depending on the average annual temperatures in the summer, June, July and August months, the cooling demand is determined. In the case of the two studied areas, no city has high temperatures in the summer months requiring additional cooling systems. In areas where no additional cooler systems are required, the cooling requirement of the building is zero.

The standard states that for a building it can be considered passive it should not have a total primary energy consumption of more than $120 \mathrm{kWh} /\left(\mathrm{m}^{2} /\right.$ year).

Total primary energy consumption as can be seen from Table 1 increases with the longitude. Total primary energy consumption is composed of energy consumed for heating, domestic hot water, auxiliary and household electricity. Total energy consumption varies between 91 and $96 \mathrm{kWh} /\left(\mathrm{m}^{2} /\right.$ year) depending on the location of the building. This variation is due to the heating demand, the energy consumption of the used equipment being approximately the same.

From the point of view of the total primary energy consumption, all the climatic zones studied by us comply with the definition of the passive house concept, namely not having a primary energy consumption of more than $120 \mathrm{kWh} /\left(\mathrm{m}^{2} /\right.$ year $)$.

The values for the primary energy needs are indicative, each building having its own consumption according to the customs and traditions of those who will work and live in them.

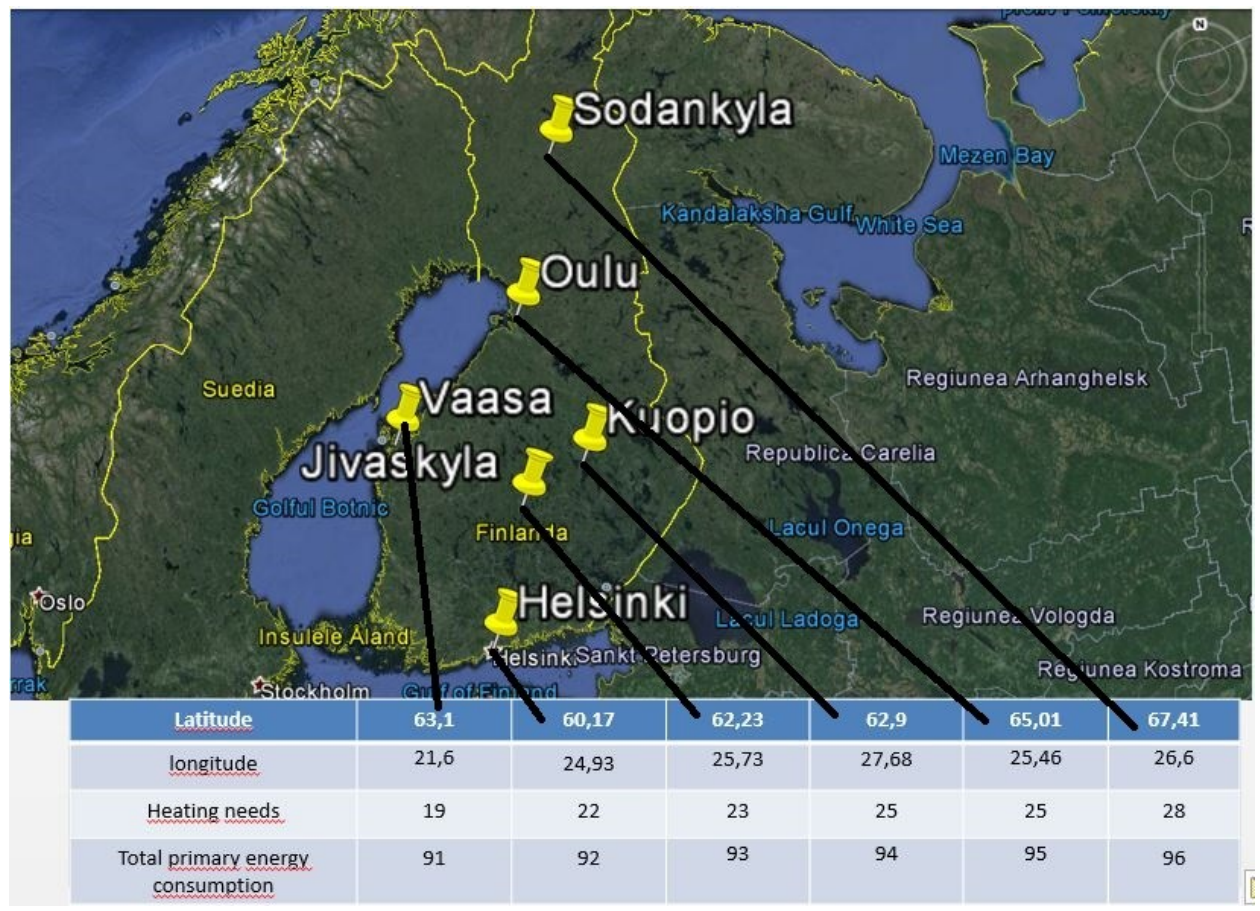

Fig. 9.Representation of results for Finland

In order to be able to implement the concept of passive building, it must comply with all the requirements imposed by the definition. In the case of the localities studied by us in the 
case of the AMVIC House in neither of the locality, both criteria are not met, so the concept cannot be applied. In the case of Vaasa, if modifications are made to the passive building model in terms of insulation, the heating requirement can be reduced to $15 \mathrm{kWh} /\left(\mathrm{m}^{2} /\right.$ year $)$ and the concept could be viable.

In order to better visualize the results obtained for both the heating demand and the total primary energy consumption according to the location area can study the Figure 9.

\section{Conclusions}

For studied cities in Finland by us, the heating demand varies between $19 \mathrm{kWh} /\left(\mathrm{m}^{2} /\right.$ year $)$

The need for the cooler due to very hot summer months is zero.

Total primary energy consumption varies between 91 and $96 \mathrm{kWh} /\left(\mathrm{m}^{2} /\right.$ year) based on the location of the building.

In terms of total primary energy consumption all climate zones we studied comply with the definition of passive house that is not the primary energy consumption of more than 120 $\mathrm{kWh} /\left(\mathrm{m}^{2} /\right.$ year $)$.

According to analyses conducted none of the studies did not meet the criteria for passive building concept maximum exceeded the value of the necessary heating.

To full fill criteria are needed for a passive house located in cold climate areas is necessary to implement new techniques. For finding new techniques are necessary sensitivity analysis. Sensitivity analysis will seek ways and techniques to reduce the need for heating.

\section{References}

1. Adamson B, Towards passive houses in cold climates as in Sweden. Division of Energy and Building Design Department of Architecture and Built Environment, Lund University, Faculty of Engineering LTH, (2011)

2. Badescu V. Theoretical and Applied Climatology 44, 187-200, (1991)

3. Boqvist A., Efficiency \& Energy Efficiency, Division of Structural Engineering,Lund Institute of Technology, Lund University, Report TVBK-1040, Lund, (2010)

4. Energy Saving Potential, The PEP-project is partially supported by the European Commission under the Intelligent Energy Europe Programme, EIE/04/030/S07.39990, (2016)

5. Teodosiu C. - Sisteme de instalaţii interioare pentru case pasive adecvate condiţiilor climatice din România.

6. http://www.soda-is.com 